\title{
Analisis Motif Kain Tradisional Indonesia: Pemaknaan Visualisasi Abstrak hingga Naturalis
}

\section{Ira Adriati Winarno}

Visual Art Department- FSRD ITB

\begin{abstract}
Indonesia is a country with various cultures. One of cultural product that interesting to be analysis is textile. Indonesian traditional textiles are made by weaving and batike techniques. Traditional textiles have a deep philosophical meaning related to the buman existence in the universe. Traditional textiles have various motifs. It is interesting to analyze the meaning of the motifs of Indonesian traditional textile. The approaches of this research are traditional Indonesian aesthetics and cultural approach. Traditional textile motifs can be categorized into geometrics, figurative, and naturalist motifs. The motifs are influenced by textile making techniques. For instance, weaving technique has limitation in motif type. Weaving technique produces geometrics motif. The other technique is batik that has freedom to produce various motifs for textile. The original Indonesian textile motifs generally are abstract motives. Figurative and naturalist motifs emerge after the entrance of other culture influence. Based on visualization analysis, abstract motif has deep meaning related to people life philosophy. Some of figurative motifs have philosophical meaning, but naturalist motifs generally do not have philosophical meaning in Indonesian people.
\end{abstract}

Keywords: traditional textile, motif, abstract, figurative, naturalist.

\section{PENDAHULUAN}

Indonesia karena lokasinya sejak awal telah bersinggungan dengan budaya-budaya luar. Orang-orang Cina, India, Persi, Arab, Asia Tenggara, Eropa, masuk perairan Indonesia, berinteraksi di kota-kota niaga Indonesia, dan meninggalkan jejak-jejak budayanya. Pluralisme budaya primordial Indonesia, mengakibatkan perkenalan dengan budaya-budaya luar itu, membangun transformasi budaya masingmasing. Budaya-budaya transformatif di wilayahwilayah primordial ini juga saling berinteraksi serta menghasilkan bentuk-bentuk budaya transformasi baru di masing-masing lokasi (Sumardjo, 2002, 75).

Bagaimana Nusantara atau Indonesia ini menjadi tempat pertemuan kebudayaankebudayaan besar di dunia, dituliskan oleh ahli sejarah Denys Lombard (2000, 1):
Sungguh tak ada satu pun tempat di dunia ini - kecuali Asia Tengah yang, seperti halnya Nusantara, menjadi tempat kehadiran hampir semua kebudayaan besar dunia, berdampingan atau lebur menjadi satu. Sekitar seribu tahun lamanya, dari abad ke-5 sampai ke-15, kebudayaan-kebudayaan India mempengaruhi Sumatera, Jawa, dan Bali, bersamaan dengan datarandataran rendah yang luas di Semenanjung Indocina. Namun, sejak abad ke-13, dan terutama sejak abad ke-15, dua pengaruh lain mulai terasa menguat yaitu Islam dan Cina. Peradaban Eropa yang hadir sejak abad ke- 16 . 
Selanjutnya Denys Lombard menekankan bahwa kawasan Nusantara itu, sebagaimana halnya Cina, bukan sebuah "kasus khusus" sejarah dunia, tetapi letak geografisnya secara khusus menekankan fungsinya sebagai persilangan, dalam arti titik pertemuan. Di sinilah terdapat laboratorium yang hebat untuk mengkaji konsep pengaruh, dan terutama konsep tradisi, akulturasi dan etnisitas, yang dewasa ini melanda ilmu-ilmu tentang dunia (ibid, 2).

Budaya asing mempengaruhi budaya asli seringkali masuk melalui perdagangan. Pada awalnya masyarakat asli tidak bertemu langsung, melainkan berinteraksi melalui artefak atau hasil budaya material suatu kebudayaan. Salah satunya artefak kain yang terdapat di daerah Toraja. Pengaruh budaya India diperoleh melalui perdagangan masyarakat Sulawesi dengan pedagang Belanda.

Pemaparan di atas memperlihatkan bahwa hasil budaya Indonesia mendapat banyak pengaruh dari berbagai budaya luar. Salah satu artefak budaya Indonesia yang telah ada sejak periode neolitikum adalah kain. Tulisan ini mencoba menganalisis motif hias yang terdapat dalam kain di kawasan Indonesia.

\section{Metodologi}

Penelitian ini menggunakan metode analisis kualitatif. Teori yang digunakan berkaitan dengan nilai estetis timur, khususnya teori yang berkaitan dengan kain tradisional
Indonesia dengan nilai filosofis yang mendasari pembuatannya. Teknik pengumpulan data melalui kaji pustaka dan observasi. Dipilih sampel penelitian kain-kain dari berbagai daerah di Indonesia yang dapat memperlihatkan keragaman motif dan maknanya.

\subsection{Teori}

Seni rupa tradisi Indonesia keberadaannya selalu erat kaitannya dengan fungsi spiritual dalam masyarakatnya. Kain di Indonesia yang dibuat dengan teknik tenun serta kain yang motifnya dibuat dengan teknik batik, keberadaannya secara historis berkaitan dengan filosofis kehidupan masyarakatnya. Dalam tulisan ini akan dipaparkan nilai estetis Timur yang berkaitan dengan kain batik maupun tenun yang ada di Indonesia. Sumber konsep tersebut berasal dari pemaparan Jakob Sumardjo dan Nian Djoemena.

\subsubsection{Ulos}

Ulos adalah kain tenun Batak yang berbentuk selendang, dengan panjang dan lebar tertentu. Setiap tenun ulos berpola hias. Pola hias ini mengikuti struktur yang dibentuk oleh garis-garis vertikal dan horizontal, yang terbagibagi dalam bidang-bidang warna. Di atas bidangbidang warna itulah ditenun bentuk-bentuk ragam hiasnya, atau beberapa jenis kain ulos membiarkannya tanpa motif ragam hias. Pada prinsipnya hanya dikenal tiga jenis warna yang merupakan lambang spiritual, yakni warna putih, hitam, dan merah.Putih adalah warna Dunia 
Atas, hitam warna Dunia Bawah, dan merah warna Dunia Tengah (Sumardjo, 2002, 134).

Pada alam pikiran Indonesia Lama, benda lambang itu tidak harus mempunyai hubungan dengan empirik, tetapi langsung berhubungan dengan arti idea dan spiritualnya. Inilah sebabnya ragam hias geometrik amat umum dipakai dalam lambang-lambang religi Indonesia Lama. Meskipun tidak menutup kemungkinan adanya peniruan bentuk-bentuk yang empirik (gambar manusia, binatang, tumbuhan). Dengan demikian lambang-lambang geometrik dan mimetik tidak harus dihubungkan dengan arti empiriknya, tetapi langsung pada arti spiritualnya (Sumardjo, 2002, 135).

\subsubsection{Lurik}

Dalam bahasa Jawa kuno lorek berarti lajur atau garis, belang dan dapat pula berarti corak. Di Jawa Tengah dan Jawa Timur kain tenun bercorak lajur atau lajuran dan belang-belang, akhirnya dinamakan kain lurik, berasal dari kata lorek, Mungkin karena corak kotak-kotak terdiri dari garis-garis yang bersilang, maka corak kotak-kotak atau cacahan dinamakan pula lurik. Corak cacahan pada lurik umumnya berukuran kecil (Djoemena, 2000, 31).

Sudah menjadi tradisi dan kebudayaan bangsa Indonesia, khususnya masyarakat Jawa Tengah dan Jawa Timur sebagai masyarakat agraris dengan kebudayaan berlandaskan Hindu Jawa, menciptakan berbagai corak dengan maksud tertentu. Corak-corak yang diciptakan ini yang dianggap karya agung yang diberi nama dan makna, dan dijadikan lambang yang mencerminkan serta unsur-unsur kepercayaan, keagungan alam semesta ciptaan Yang Maha Kuasa, pemujaan pada leluhur, falsafah hidup, harapan, tauladan, peringatan, dan sebagainya. Di samping itu dijadikan pegangan dalam menjalani kehidupan disertai harapan akan memberi kehormatan, keluhuran budi, perlindungan dan kemakmuran bagi pemakai (Djoemena, 2000, 43).

Beberapa motif atau corak lurik yang sakral adalah Corak Kluwung/Klowong yang berarti pelangi. Ada anggapan bahwa pelangi merupakan keajaiban alam dan ciptaan serta tanda kebesaran Tuhan Maha Pencipta. Oleh karena itu corak Kluwung dianggap sakral serta mempunyai tuah untuk menolak bala. Motif lain adalah Telu-pat yang diciptakan oleh Sri Sultan Hamangku Buwono I. Motif tersebut berasal dari bahasa Jawa telu (tiga) dan papat (empat), adalah corak lajuran yang berjumlah tujuh, terdiri dari satu satuan kelompok dengan jumlah empat lajur, dan yang satu lagi dengan jumlah tiga lajur. Angka tujuh merupakan angka keramat, yang dalam kepercayaan tradisional Jawa, Kejawen, melambangkan kehidupan dan kemakmuran (Djoemena, 2000, 57 -62). 
Gambar 1 Lurik Kluwung

Sumber: Djoemena, 2000

\subsubsection{Batik}

\section{Berdasarkan pemaparan Jakob} Soemardjo disebutkan bahwa seni batik merupakan produk pemikiran manusia sawah dapat disimak dari motif-motif yang merupakan simbol kosmologi mereka. Bukti otentitas itu terletak pada simbol-simbol gambar batiknya. Di samping itu juga pada lembaran kain yang dibakukkan untuk dibatik. Begitu pula proses pembatikan dapat dibaca sebagai bentuk ritual yang tidak berani dilanggar oleh pembuat batik.

Dalam pemakaiannya sebagai kain, batik memperhitungkan mana bagian badan belakang dan mana bagian badan depan. Sebagaimana dikenal, bahwa kain batik letak depan dan belakang memiliki nilai yang berbeda. Perhitungan bagian depan dan belakang memiliki nilai yang berbeda. Perhitungan bagian depan dan belakang terpola dalam lebanr kain itu sendiri yang terdiri dari sedikitnya dua setengah kacu. Yang disebut kacu adalah bentuk empat persegi. Sebuah kain batik dengan demikian sedikitnya, terdiri dari dua setengah kacu. Satu kacu adalah bentuk persegi empat. Pola ini menggambarkan mancapat kalimo pancer dengan empat arah ruang dan satu pusat tepat di bagian tengah kacu. Ketika budaya sawah mengenal konsep-konsep religi India, maka kacu dapat berarti mandala. Mandala adalah lingkaran (yang tak terbatas, absolut) yang berada dalam persegi empat (terbatas). Mandala adalah kesatuan yang transenden dan imanen. Dengan ukuran dua kacu, maka terdapat dua pasangan kembar mandala, yakni mandala bagian belakang badan dan mandala bagian depan badan. Setengah kacu, selebihnya untuk wiron. Batik adalah pola mandala membawa simbol paradoks, yakni hadirnya yang terbatas di dunia terbatas, hadirnya yang transenden di dunia imanen, hadirnya daya adikodrati di dunia kodrat, menyatunya purusha dan pakerti.

Di samping pola mandala, batik juga mengenal pola parang atau miring, berupa garis diagonal yang memenuhi seluruh bidang kain batik. Pola parang juga gambaran paradoks. Garis diagonal merupakan harmoni antara garis vertikal dan horizontal. Garis diagonal adalah garis vertikal sekaligus garis horizontal. Pembagian pola parangsama dengan pembagian pola mandala, yakni satu kacu dibagi 2, kemudian 4, 16, 32, 64. Banyaknya garis miring atau diagonal dalam satu kacu dan dalam satu lembar kain batik tergantung pada pembagian mandalanya, apakah mandala 4 bagian, 16 bagian dan sebagainya.

Pengisian bidang-bidang miring biasanya pola dualism antagonistik. Kehadiran pasangan 
dualistik semacam ini juga bermakna paradoks, karena bentuk berlawanan tetapi kembar (saling terbalik), disatukan dalam satu motif. Motif ini dikenal sebagai batik parang (Sumardjo, 2010, 150)

Berdasarkan pemikiran tersebut terlihat bahwa makna kain yang ada di Indonesia berkaitan dengan nilai filosofis kehidupan mereka. Bentuk-bentuk yang muncul dalam motif kain tidak sekedar hiasan,

\subsection{Teknik Pengumpulan Data}

Teknik pengumpulan data dalam penelitian ini menggunakan kaji pustaka dan observasi. Kaji pustaka berkaitan dengan teori estetika timur, kain dari berbagai daerah di Indonesia. Observasi dilakukan pada beberapa kain yang menjadi sampel penelitian ini. Observasi diperlukan untuk lebih mengetahui tekstur, dan pewarnaan pada kain sampel.

\section{Kain Tradisional Indonesia}

Indonesia merupakan Negara Kepulauan yang memiliki keragaman hasil budaya, salah satunya keragaman jenis kain. Kain yang umumnya dibuat dengan teknik menenun maupun membatik. Dalam budaya Indonesia, pembatik, penenun, penganyam pra-modern dilakukan oleh perempuan. Semua ini berhubungan dengan bahan utamanya, yakni kain. Kain dalam artefak-artefak seni purba Indonesia merupakan simbol perempuan. Alam pikiran primordial memaknai kain sebagai kategori perempuan (Sumardjo, 2010, 146).
Alam pikiran purba Austronesia ini kiranya masih lestari dalam alam pikiran orang sawah di Jawa, sehingga pembatik hanya dilakukan oleh perempuan. Begitu pula penenun di daerah ladang. Bahkan penganyam dari dedauann kering hanya dilakukan oleh perempuan (ibid, 147).

Material yang digunakan sebagai kain di beberapa daerah seperti di Minangkabau, Sulawesi, dan Papua dimulai dengan kain yang berasal dari kulit kayu, kemudian berkembang kemampuan dalam mengolah kapas sehingga mampu membuat benang dan berlanjut dengan kemampuan menenun.

Perkembangan motif pada kain di Indonesia memperlihatkan bagaimana pengaruh luar memperkaya motif kain di Indonesia. Pengaruh Hindu Budha melalui India, pengaruh Cina dan kawasan Asia lainnya, pengaruh Islam dan dilanjutkan dengan pengaruh Eropa. Perkembangan motif tersebut dapat dilihat pada motif batik maupun motif kain dengan teknik tenun di berbagai kawasan di Indonesia. Pada akhirnya pengaruh-pengaruh tersebut bertransformasi dengan budaya asli Indonesia sehingga memunculkan motif khas Indonesia dengan perpaduan beragam budaya asing.

\section{Analisis Pemaknaan Visualisasi Motif Kain Tradisional Indonesia}

Masyarakat Baduy Luar memiliki tradisi menenun dengan motif-motif geometris yang memiliki makna sesuai dengan filosofi kehidupan mereka. Salah satu motif tajur pinang yang digunakan oleh perempuan. Maknanya 
berkaitan dengan keturunan yang memiliki budi pekerti yang baik.

\section{Gambar 2 Motif Tajur Pinang}

Sumber: Maktufa, 2013

Motif kotak-kotak hitam putih pada kain di Bali yang biasa digunakan untuk kelengkapan upacara, memiliki makna keseimbangan dari berbagai serangan. Motif lain di daerah Bali menggunakan motif yang berasal dari cerita Wayang Hindu. Misalnya tampak dalam kain saput songket atau kampub songket, motif yang tampak adalah bentuk wayang, ikan, monyet, burung, gajah, ular, harimau, kala, dan boma. Kain tersebut memperlihatkan penggunaan benang keemasan. Penggunaan motif yang erat kaitan dengan nilai keagamaan Hindu tersebut memperlihatkan pengaruh dari agama Hindu dalam masyarakat Bali.

\section{Gambar 3 Kampuh Songket}

Sumber: Maxwell, 2003
Motif-motif kain yang geometrik maupun motif abstrak di beberapa kawasan di Indonesia umumnya memiliki makna filosofis yang terkait dengan pandangan hidup masyarakatnya. Salah satunya motif kain dalam suku Minangkabau Sumatera Barat. Motif kain di kawasan tersebut berasal dari filosofis hidup masyarakatnya yang masuk dalam adat mereka, maupun motif yang berasal dari alam seperti motif flora dan fauna. Motif geometrik yang sarat makna antara lain motif pada Kain Tangkuluak yang biasa digunakan untuk menutup kepala di daerah Pandai Sikek/Koto Baru, terdiri dari komposisi bentukbentuk geometrik yang sangat indah dengan benang perak. Dalam selembar kain tersebut terdapat beberapa makna yang diambil dari bentuk kacang tanah yang terbelah atau disebut balah kacang. Makna dari motif tersebut adalah harus adanya keseimbangan dalam sikap seorang yang berasal dari suku Minangkabau dalam kehidupan ini. Motif lain adalah Barantai Bugih yang merupakan pengulangan dari bentuk permata. Terdapat Barantai Putiah dan Barantai Merah. Bentuk tersebut mengandung makna 
perlunya bekerja sama untuk mencapai kekuatan dalam masyarakat Minangkabau.
Gambar 4 Motif Kain Tangkuluak Sumber: Summerfield, 1999

Pua adalah kain upacara di Kalimantan yang bermotif figur antropomorfik berpadu dengan figur manusia dan abstraksi tumbuhan. Pua merupakan kain yang digunakan dalam upacara-upacara adat penting masyarakat suku Iban di Kalimantan. Salah satu upacara penting adalah ketika para prajurit menyerahkan kepala musuh kepada perempuan pemuka adat di rumah panjang. Pembuatan motif tersebut merupakan hasil pertemuan penenun dengan roh nenek moyang dalam mimpi para penenun.
Gambar 5 Kain Pua

Sumber: Taylor, 1991

Tenun di daerah Tana Toraja dikenal tenun Galumpang yang dibuat di daerah Galumpang Makki di Kabupaten Mamuju. Kain tenun Galumpang digunakan sebagai porisitutu yaitu kain yang digunakan untuk menutup peti jenazah. Motif kain Galumpang berwarna alami merah bata, biru tua dan biru muda dihiasi dengan motif geometric membentuk dua anak panah dengan arah berlawanan. Bentuk ini merupakan lambing suatu kekuatan yang berlawanan yang member arti bagi kehidupan manusia, selain itu terdapat motif hias berbentuk leluhur. 
Masih di kawasan Toraja dikenal kain yang diberi motif hiasan dengan teknik melukiskan di atas permukaan kain. Nama kain tersebut sarita dan maa. Kain tersebut menunjukkan pengaruh dari kain patola India.

Gambar 7 Maa

Sumber: Maxwell, 2003

Di kawasan Lampung terdapat jenis kain tampan yang biasa digunakan dalam upacara adat. Motif yang tervisualisasikan dalam kain tersebut merupakan pengaruh dari China dan Thailand dengan simbol-simbol visual yang bermakna pohon kehidupan maupun erat kaitannya dengan filosofi Budha. Sebagai contohTampan gaya pasisir dari Lampung memperlihatkan upacara kelahiran bayi. Motif bentuk figuratif manusia, hewan, tumbuhan, dan perahu.

\section{Gambar 8 Kain Tapis \\ Sumber: Taylor, 1991}

Masuknya agama Islam ke kawasan Indonesia memberikan pengaruh pada motif kain di beberapa kawasan yang penduduknya kemudian memeluk agama Islam. Penggunaan kaligrafi Arab menjadi salah motif kain yang berkembang setelah Islam masuk. Kain Batik dengan motif kaligrafi terlihat di kawasan Jambi, Cirebon, dan Jawa Tengah. Di Aceh, kaligrafi Arab tampak pada kain ija tobulee kasab bungong kalimah yang ditenun dengan benang perak yang menuliskan pengulangan nama Allah.
Gambar 9 Motif kaligrafi Arab dalam ija tobulee kasab bungong kalimah

Sumber: Maxwell, 2003 
Motif batik di kawasan Priangan atau kawasan Jawa Barat khususnya batik Ciamis, Garut, dan Tasikmalaya memperlihatkan kecenderungan penggunaan motif figuratif. Motif parang yang merupakan motif batik klasik dari Jawa Tengah menjadi salah satu motif klasik yang digunakan di Jawa Barat. Pengrajin batik di Jawa Barat menambahkannya dengan motif flora maupun fauna misalnya motif Rereng Suliga perpaduan motif parang dengan motif kupukupu maupun motif Rereng Akar yang merupakan komposisi motif parang dengan motif tumbuhan.

\section{Gambar 10 Motif Rereng Suliga}

Sumber: Pradito dkk, 2010

\section{Gambar 11 Motif Rereng Akar}

Sumber: Pradito dkk, 2010

Selanjutnya motif di kawasan Priangan seperti di Garut menggunakan motif burung merak dalam batik motif Merak Ngibing. Bentuk burung merak yang distilasi dengan warna cerah biru merah. Pedoman batik kacu dengan bagian tengah terlihat pada motif Mojang Priangan, hanya saja motif pada bagian badan yang merupakan stilasi kupu-kupu dan buanga-bunga tidak mengindikasikan makna lain di samping ingin menonjolkan keindahan alam. Ditegaskan oleh Pradito dkk (2010, 32), bahwa batik Garut tak mengenal apa yang disebut dengan motif larangan karena semata-mata digunakan untuk kebutuhan sandang sehari-hari yang dikenakan sebagai sinjang (kain panjang). Motif yang diambil dari flora fauna di sekitar dalam aplikasinya menggunakan warna-warna yang cerah dengan peletakkan komposisi menyerupai batik Tionghoa atau batik pesisir dengan adanya tipe batik Papangkah Latar Limar Bilik, atau pengaruh Batik Jawa Hokokaipengaruh Jepang dalam tipe batik Isuk Sore Papangkah Bulu Hayam.
Gambar 12 Merak Ngibing

Sumber: Pradito dkk, 2010 
Gambar 13 Mojang Priangan

Sumber: Pradito dkk, 2010
Gambar 15 Terang Bulan

Sumber: Pradito dkk, 2010
Gambar 14 Isuk Sore Papangkah Bulu Hayam

Sumber: Pradito dkk, 2010

Di Tasikmalaya motif klasik rereng masih dibuat seperti motif Rereng Suliga, tetapi umumnya kekhasan batik Tasikmalaya adalah bagaimana pengrajin membuat stilasi tumbuhan maupun hewan dalam selembar kain batik, misalnya motif Terang Bulan yang terdiri dari pengulangan dua burung dengan tumbuhan pada latar hitam. Selain itu motif Papangkah Rerengyaitu stilasi tumbuhan di atas motif parang. Jenis motif yang lebih bebas tampak pada Motif Mer Sawah.
Gambar 16 Motif Mer Sawah

Sumber: Pradito dkk, 2010

Motif realis muncul dalam batik-batik yang dikembangkan oleh orang Eropa di Pulau Jawa. Salah satunya motif batik kain sarung yang dibuat oleh Lien Metzelaar, Pekalongan Jawa Tengah diambil dari cerita Si Topi Merah atau Red Riding Hood diproduksi sekitar tahun 1895. Dalam batik tersebut terlihat sosok anak perempuan bertopi merah dengan seekor srigala. Motif tadi menempati bagian badan kain, sedangkan bagian wiron masih menggunakan stilasi bunga. Batik dengan motif yang realis tersebut mencirikan gaya Eropa seperti disebutkan oleh Maxwell (2003, 382). Tidak terdapat makna filosofis dalam motif batik yang dikembangkan oleh komunitas Eropa tersebut. 
Gambar17 Red Riding Hood

Sumber: Maxwell, 2003

\section{Di Desa Silungkang Sumatera Barat} terdapat kain yang disebut dalamak untuk menutup sirih atau makanan dengan motif figurativeyang berasal dari karakter-karakter China seperti ikan, monyet, kelinci, kepiting, dan beragam tumbuhan. Pembuatan motif tersebut dengan menggunakan teknik sulam. Tidak terdapat makna khusus untuk motif tersebut. Visualisasi motif tersebut dipengaruhi oleh keberadaan etnik China di Minangkabau. Hanya saja bila dicemati penggunaan motif binatang tersebut beberapa berkiatan dengan shio dalam kebudayaan Cina, sedangkan motif ikan dalam beberapa mitos China menjadi binatang jelmaan seorang kaisar seperti diungkapkan dalam cerita Chen Guangrui seorang Sarjana, pada masa kecilnya ia melepaskan seekor ikan emas yang telah dibelinya ke dalam sungai. Ikan tersebut ternyata Longwang (Raja Naga) Sungai. Di kemudian hari, ia diselamatkan oleh raja tersebut (Werner, 2008).

\section{Gambar18 Dalamak}

Sumber: Summerfield, 1999

Berdasarkan pemaparan di atas mengenai motif kain di Indonesia terlihat motif abstrak hingga geometrik umumnya merupakan motif asli Indonesia yang belum mendapat pengaruh dari kebudayaan asing, meskipun demikian terdapat motif geometrik yang berasal dari budaya asing misalnya motif geometrik yang dipengaruhi oleh budaya India yang masuk ke Indonesia. Selanjutnya banyak motif figuratidf yang dipengaruhi oleh kebudayaan Cina misalnya dalam kain Tapis Lampung. Pengaruh Islam memperkaya motif di Indonesia dengan penggunaan kaligrafi. Motif realis masuk ke Nusantara terutama karena pengaruh Eropa.

Keragaman visualisasi motif tersebut berkaitan dengan nilai filosofis yang terkandung dalam motif tersebut. Motif abstrak, geometrik, dan figuratif umumnya memiliki makna filosofis yang mendalam. Erat kaitannya dengan hubungan manusia dengan kosmos. Motif realis yang berasal dari Eropa umumnya terlihat dalam motif batik pesisir utara Jawa, pada umumnya motif tersebut tidak memiliki makna yang 
mendalam, melainkan hanya merupakan deskripsi dari obyek-obyek yang ada. Motif realis memperlihatkan narasi mengenai obyek-obyek yang ditampilkan dalam motif kain, selain itu unsur keindahan dari segi bentuk, komposisii, maupun penggunaan warna menjadi unsur penting dalam visualisasi kain tersebut. Penggunaan kain lebih banyak untuk keseharian daripada penggunaan yang berkaitan dengan upacara-upacara adat.

Gambar 19 Analisis Motif, Makna, dan Kebudayaan yang Mempengaruhi Sumber: Penulis lebih banyak profan, tanpa makna filosofis. Umumnya motif figuratif hingga naturalis merupakan pengaruh bangsa lain yang masuk dalam budaya Indonesia. Selain itu proses masuknya pengaruh budaya asing ke Indonesia dapa berlangsung secara langsung maupun melalui perdagangan artefak-artefak.

\section{UCAPAN TERIMA KASIH}

Ucapan terima kasih disampaikan kepada Program Proyek Pengembangan ITB III 2014 yang telah memberikan dana penelitian mengenai karya Seni Rupa Indonesia Lama. Terima kasih pula kepada Program Studi Desain Komunikasi Visual FSRD ITB, tulisan ini merupakan pengembangan dari tulisan sebelumnya yang dipresentasikan dalam Seminar DKV 2014.

\section{DAFTAR PUSTAKA}

Doellah, S.

2002. Batik: Pengaruh Zaman dan Lingkungan, Danar Hadi, Solo.

Djoemena, D.

2000. Lurik: Garis-garis Bertuah, Djambatan, Jakarta.

Kartiwa, S.

2007. Tenun Ikat, Gramedia, Jakarta.

menghasilkan motif yang figuratif hingga naturalis. Terdapat perbedaan makna dalam visualisasi motif hiasan kain di Indonesia, makna filosofis lebih banyak terdapat dalam motif abstrak dan geometrik, figuratif, dan kaligrafi. Makna filosofis seringkali berkaitan dengan mitos dan legenda suatu suku. Motif naturalis

\section{Temun Ikat, Gramedia, Jakarta.}

Lombard, D.

2000. Nusa Jawa: Silang Budaya; Batas-batas Pembaratan, Gramedia, Jakarta.

Maktufkha, N.

2013. Kajian Nilai Estetis Seni Tenun yang Dihasilkan oleh Perempuan Suku Baduy Luar 
(Periode 2010 - 2013), Tesis, Institut Teknologi Bandung, Bandung.

Maxwell, R.

2003. Textiles of Southeast Asia: Tradition, Trade, and Transformation, Periplus, Singapore.

Maxwell, Robyn.

2003. Sari To Sarong, National Gallery of Australia, Victoria.

Pradito, D., Jusuf, H., dan Atik, K. ed.

2010. The Dancing Peacock: Colours and Motifs of Priangan Batik, Gramedia Pustaka Utama, Jakarta.

Sumardjo, J.

2002. Arkeologi Budaya Indonesia: Pelacakan Hermeneutis-Historis terbadap Artefakartefak Kebudayaan Indonesia, Qalam, Yogyakarta.

Sumardjo, D.

2010. Estetika Paradoks (edisi revisi), Sunan Ambu Press, Bandung.

Summerfield, J., A., ed.

1999. Walk in Splendor, University of California, California.

Werner, E.T.C.

2008. Mitos dan Legenda China: Kumpulan Kisah Fantastis dan Rahasia di Baliknya, terj., P.T. Gramedia Pustaka Utama, Jakarta. 